\title{
New Cobalt(I) Complexes Derived from Dicarbonyltricyanocobaltate(I)
}

\author{
By John Bercaw, Giovannt Guastalla, and Jack Halpern* \\ (Department of Chemistry, The University of Chicago, Chicago, Illinois 60637)
}

Summary The preparation and characterization of several series of mixed ligand cobalt(I) complexes of the types $\left[\mathrm{Co}(\mathrm{CN})_{2}(\mathrm{CO})_{2}\left(\mathrm{PR}_{3}\right)\right]^{-}, \quad\left[\mathrm{Co}(\mathrm{CN})_{2}(\mathrm{CO})\left(\mathrm{PR}_{3}\right)_{2}\right]^{-}$, and $[\mathrm{Co}-$ $\left.(\mathrm{CN})(\mathrm{CO})_{2}\left(\mathrm{PR}_{3}\right)_{2}\right]$, prepared by the reactions of tertiary phosphines $\left(\mathrm{PR}_{3}\right)$ with $\left[\mathrm{Co}(\mathrm{CN})_{3}(\mathrm{CO})_{2}\right]^{2-}$, are described and some novel aspects of their chemistry are discussed.

WE have previously described the preparation of the cobalt(I) complex, $\left[\mathrm{Co}(\mathrm{CN})_{3}(\mathrm{CO})_{2}\right]^{2-}(1)$, by the carbonylation of aqueous solutions of either $\left[\mathrm{Co}(\mathrm{CN})_{5}\right]^{3-}$ or $\left[\mathrm{Co}(\mathrm{CN})_{5} \mathrm{H}\right]^{3-}$ (refs. 1 and 2).

We now describe the preparation of several new series of mixed ligand cobalt(I) complexes of the types $\left[\mathrm{Co}(\mathrm{CN})_{\mathbf{2}^{-}}\right.$ $\left.(\mathrm{CO})_{2}\left(\mathrm{PR}_{3}\right)\right]^{-}, \quad\left[\mathrm{Co}(\mathrm{CN})_{2}(\mathrm{CO})\left(\mathrm{PR}_{3}\right)_{2}\right]^{-}$, and $\left[\mathrm{Co}(\mathrm{CN})(\mathrm{CO})_{2^{-}}\right.$ $\left(\mathrm{PR}_{3}\right)_{2}$ ] by reactions of tertiary phosphines $\left(\mathrm{PR}_{3}\right)$ with $(\mathbf{1})$. Representative examples, together with their i.r. bands, are listed in the Table. Satisfactory elemental analyses were obtained for all these compounds.

TABLE

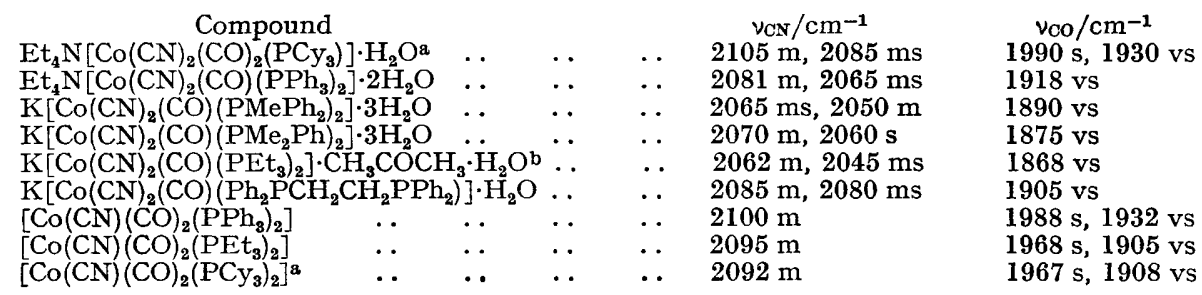

a $\mathrm{Cy}=$ cyclohexyl. $\quad$ ' Recrystallized from acetone; formula confirmed by ${ }^{1} \mathrm{H}$ n.m.r. 
Complexes of the type $\left[\mathrm{Co}(\mathrm{CN})_{2}(\mathrm{CO})\left(\mathrm{PR}_{3}\right)_{2}\right]^{-}$were synthesized (in ca. $50 \%$ yields) by reaction of $\left[\mathrm{Co}(\mathrm{CN})_{3}(\mathrm{CO})_{2}\right]^{2-}$ with the appropriate phosphine ( $2 \mathrm{~mol}$. equiv.) under homogeneous conditions in aqueous methanol $(1: 1)$. The

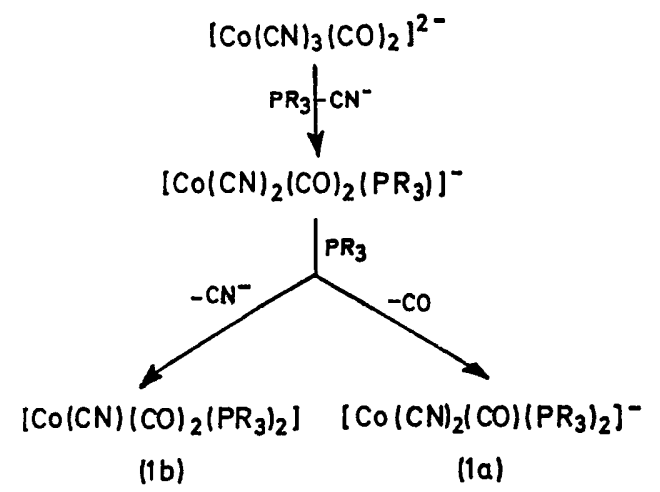

neutral bis-phosphine compounds of the type $\left[\mathrm{Co}(\mathrm{CN})(\mathrm{CO})_{2^{-}}\right.$ $\left(\mathrm{PR}_{3}\right)_{2}$ ] were prepared heterogeneously by the addition of liquid phosphine or a solution in butanol of a solid phosphine to an aqueous solution of $(\mathbf{1})$. Presumably $\left[\mathrm{Co}(\mathrm{CN})_{2}(\mathrm{CO})\right.$ $\left.\left(\mathrm{PR}_{3}\right)_{2}\right]^{-}$and $\left[\mathrm{Co}(\mathrm{CN})(\mathrm{CO})_{2}\left(\mathrm{PR}_{3}\right)_{2}\right]$ are derived from the common intermediate $\left[\mathrm{Co}(\mathrm{CN})_{2}(\mathrm{CO})_{2}\left(\mathrm{PR}_{3}\right)\right]^{-}$(according to equation 1) through alternative paths involving the dissociation of $\mathrm{CO}$ or $\mathrm{CN}^{-}$respectively, the latter being favoured by the two-phase reaction medium where $\mathrm{CN}^{-}$is removed by the aqueous phase. The preparation of several complexes of this type, i.e. $\left[\mathrm{Co}(\mathrm{CN})(\mathrm{CO})_{2}\left(\mathrm{PPh}_{3}\right)_{2}\right]$ and $\left[\mathrm{Co}(\mathrm{CN})(\mathrm{CO})_{2}\left(\mathrm{PPhEt}_{2}\right)_{2}\right]$ by a different route, has recently been reported. ${ }^{3}$ In only one case, i.e. $\left[\mathrm{Co}(\mathrm{CN})_{2}(\mathrm{CO})_{2}\{\mathrm{P}-\right.$

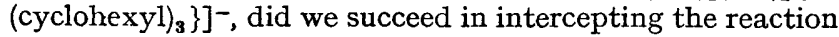
after the first substitution step and in isolating a pure salt of the monophosphine complex. Presumably steric factors oppose further substitution in this case although the corresponding bis(phosphino)-complex, $\left[\mathrm{Co}(\mathrm{CN})(\mathrm{CO})_{2}\{\mathrm{P}\right.$ (cyclohexyl $\left.)_{3}\right\}_{2}$ ] could be obtained by reaction with additional $\mathrm{P}(\text { cyclohexyl })_{3}$.

All the compounds were decomposed by oxygen; their reactivities ranged from pyrophoric for $\mathrm{K}\left[\mathrm{Co}(\mathrm{CN})_{2}(\mathrm{CO})\right.$ $\left.\left(\mathrm{PEt}_{3}\right)_{2}\right]$ and $\mathrm{K}\left[\mathrm{Co}(\mathrm{CN})_{2}(\mathrm{CO})\left(\mathrm{PMe}_{2} \mathrm{Ph}\right)_{2}\right]$ to a slow decomposition for $\mathrm{Et}_{4} \mathrm{~N}\left[\mathrm{Co}(\mathrm{CN})_{2}(\mathrm{CO})\left(\mathrm{PPh}_{3}\right)_{2}\right]$ and $\left[\mathrm{Co}(\mathrm{CN})(\mathrm{CO})_{2}\right.$ $\left.\left(\mathrm{PPh}_{3}\right)_{2}\right]$. Alkaline aqueous or alcoholic solutions of the

1 J. Halpern and M. Pribanic, J. Amer. Chem. Soc., 1971, 93, 96.

2 G. Guastalla, J. Halpern, and M. Pribanic, J. Amer. Chem. Soc., in the press.

${ }^{3}$ M. Bressan, B. Corain, P. Rigo, and A. Turco, Inorg. Chem., 1970, 9, 1733.

4 G. N. Schrauzer and E. Deutsch, J. Amer. Chem. Soc., 1969, 91, 3341.

${ }^{5} \mathrm{~J}$. Halpern and M. Pribanic, Inorg. Chem., in the press. complexes are stable for several days in the absence of oxygen.

Our initial examination of the chemistry of these new complexes has revealed the following features.

(i) Lowering the $\mathrm{pH}$ of an aqueous solution of $\left[\mathrm{Co}(\mathrm{CN})_{2}\right.$ (CO) $\left.\left(\mathrm{PEt}_{3}\right)_{2}\right]^{-}\left(\lambda_{\max } 232 \mathrm{~nm} ; \epsilon 3.4 \times 10^{4}\right)$ from 11 to 4 with $\mathrm{HClO}_{4}$ results in a reversible spectral change and in the formation of a new species $\left(\lambda_{\max } 247 \mathrm{~nm} ; \epsilon 2.1 \times 10^{4}\right)$, presumably the hydrido-complex $\left[\mathrm{HCo}(\mathrm{CN})_{2}(\mathrm{CO})\left(\mathrm{PEt}_{3}\right)_{2}\right]$, formed in accord with reaction (2) and having a $\mathrm{p} K_{\mathbf{a}}$ of $c a .5$.

$$
\left[\mathrm{Co}(\mathrm{CN})_{2}(\mathrm{CO})\left(\mathrm{PEt}_{3}\right)_{2}\right]^{-}+\mathrm{H}^{+} \rightleftharpoons\left[\mathrm{HCo}(\mathrm{CN})_{2}(\mathrm{CO})\left(\mathrm{PEt}_{3}\right)_{2}\right] \text { (2) }
$$

(ii) In contrast to certain other cobalt(I) complexes, e.g. $\left[\mathrm{Co}(\mathrm{dmg})_{2}\left(\mathrm{PR}_{3}\right)\right]^{-}$, these complexes exhibit only weak nucleophilicity toward organic halides as reflected in the very slow reactions of $\left[\mathrm{Co}(\mathrm{CN})_{2}(\mathrm{CO})\left(\mathrm{PPh}_{3}\right)_{2}\right]^{-}$and $\left[\mathrm{Co}(\mathrm{CN})_{2}-\right.$ (CO) $\left.\left(\mathrm{PEt}_{3}\right)_{2}\right]^{-}$with benzyl bromide in methanol to yield rather unstable products which have not yet been characterized. The low nucleophilicities of these complexes, as well as their relatively low basicities toward protonation [equation (2)], presumably reflect the strong tendency of the $\mathrm{CO}$ ligand to stabilize cobalt(I) against oxidation.

(iii) $\left[\mathrm{Fe}(\mathrm{CN})_{6}\right]^{3-}$ reacts rapidly and quantitatively with $\left[\mathrm{Co}(\mathrm{CN})_{2}(\mathrm{CO})\left(\mathrm{PEt}_{3}\right)_{2}\right]^{-}$in alkaline solution in the stoicheiometric ratio $4 \cdot 0: 1$. In accord with equation (3), one $\mathrm{CO}_{3}{ }^{2-}$ ion is produced together with a dark orange compound (whose barium salt exhibits the characteristic i.r. bands of $\mathrm{PEt}_{3}$ in addition to $\mathrm{CN}$ bands at 2125,2065 , and $2040 \mathrm{~cm}^{-1}$ ) tentatively identified as $\left[(\mathrm{CN})_{5} \mathrm{Fe}-\mathrm{CN}-\mathrm{Co}(\mathrm{CN})_{2}\left(\mathrm{PEt}_{3}\right)_{2}-\right.$ $\left.\left(\mathrm{OH}_{2}\right)\right]^{3-}$, i.e. the analogue of the ion $\left[(\mathrm{CN})_{5} \mathrm{Fe}-\mathrm{CN}-\mathrm{Co}\right.$ $\left.(\mathrm{CN})_{5}\right]^{6-}$ which is the product of the corresponding oxidation of $\left[\mathrm{Co}(\mathrm{CN})_{5}\right]^{4-}$ by $\left[\mathrm{Fe}(\mathrm{CN})_{6}\right]^{3-.5}$

$$
\begin{gathered}
{\left[\mathrm{Co}(\mathrm{CN})_{2}(\mathrm{CO})\left(\mathrm{PEt}_{3}\right)_{2}\right]^{-}+4\left[\mathrm{Fe}(\mathrm{CN})_{6}\right]^{3-}+4 \mathrm{OH}^{-}} \\
\rightarrow 3\left[\mathrm{Fe}(\mathrm{CN})_{6}\right]^{4-}+\mathrm{CO}_{3}{ }^{2-}+\left[(\mathrm{CN})_{5} \mathrm{Fe}-\mathrm{CN}-\mathrm{Co}(\mathrm{CN})_{2^{-}}\right. \\
\left.\quad\left(\mathrm{PEt}_{3}\right)_{2}\left(\mathrm{H}_{2} \mathrm{O}\right)\right]^{3-}+\mathrm{H}_{2} \mathrm{O}
\end{gathered}
$$

The ready oxidation of the $\mathrm{CO}$ ligand in this reaction is of considerable novelty and interest. Further studies on this and other aspects of the chemistry of these new cobalt(I) complexes are in progress.

Support of this work by the National Science Foundation and the National Institutes of Health is gratefully acknowledged.

(Received, September 20th, 1971; Com. 1650.) 